\title{
Political ecologies of biopower: diversity, debates, and new frontiers of inquiry
}

\author{
Connor Joseph Cavanagh ${ }^{1}$ \\ Norwegian University of Life Sciences, Norway
}

\begin{abstract}
This article reviews recent literature on the political ecologies of conservation and environmental change mitigation, highlighting the biopolitical stakes of many writings in this field. Although a large and apparently growing number of political ecologists engage the concept of biopower directly - in its Foucauldian, Agambenian, and various other formulations - recent writings across the humanities and social sciences by scholars utilizing an explicitly biopolitical lens provide us with an array of concepts and research questions that may further enrich writings within political ecology. Seeking to extend dialogue between scholars of biopolitics, of political ecology, and of both, then, this article surveys both new and shifting contours of the various ways in which contemporary political ecologies increasingly compel us to bring the very lives of various human and nonhuman populations, as Foucault once put it, "into the realm of explicit calculations." In doing so, 'new frontiers' of biopolitical inquiry are examined related to: i) species, varieties, or 'multiple modes' of governmentality and biopower; ii) critical (ecosystem) infrastructure, risk, and 'reflexive' biopolitics; iii) environmental history, colonialism, and the genealogies of biopower, and iv) the proliferation of related neologisms, such as ontopower and geontopower.
\end{abstract}

Key words: Political ecology; biopower; conservation; environmental change; Foucault

\section{Résumé}

Cet article est une revue de la littérature récente sur les écologies politiques de la conservation et de l'atténuation des changements environnementaux, qui met en évidence les enjeux biopolitiques de nombreux écrits dans ce domaine. De nombreux écologistes politiques engagent directement le concept de biopouvoir - dans ses formulations foucaldienne, agambénienne et diverses autres. Des écrits récents dans le domaine des sciences humaines et sociales, élaborés par des chercheurs utilisant une optique explicitement biopolitique, nous offrent un ensemble de concepts et de questions de recherche susceptibles d'enrichir davantage les écrits sur l'écologie politique. Cet article examine les différentes manières dont les écologies politiques contemporaines nous obligent à amener la vie de diverses populations humaines et non humaines, comme Foucault l'a dit, «dans le domaine des calculs explicites». Il élargit le dialogue entre les chercheurs en biopolitique et en écologie politique. Ce faisant, les «nouvelles frontières» de l'enquête biopolitique sont examinées concernant: 1) les espèces, les variétés ou les «modes multiples» de gouvernementalité et de biopouvoir; 2) infrastructure écosystémique critique, risque et biopolitique «réflexive»; 3) l'histoire environnementale, le colonialisme et les généalogies du biopouvoir; 4) la prolifération de concepts connexes, comme ontopower et geontopower.

Mots clés: Écologie politique; biopouvoir; préservation; changement environnemental; Foucault

\footnotetext{
${ }^{1}$ Dr. Connor Joseph Cavanagh, Postdoctoral Fellow, Department of International Environment and Development Studies (Noragric), Norwegian University of Life Sciences (NBMU), Norway. Email: connor.cavanagh "at" nmbu.no. I would like to thank the editors of this collection for their work in seeing the Special Section through to publication, as well as to the editors and reviewers for helpful comments and criticisms on previous versions of the manuscript. This article was written while I was in receipt of funding from the Research Council of Norway FRIPRO-Toppforsk project Greenmentality: $a$ political ecology of the green economy in the Global South, which I gratefully acknowledge. This is the third article in Hanne Svarstad, Tor A. Benjaminsen and Ragnhild Overå (eds.). 2018. "Power in political ecology", Special Section of the Journal of Political Ecology 25: 350-425.
} 


\section{Resumen}

Este artículo hace una revisión de la literatura reciente sobre las ecologías políticas de la conservación y la mitigación del cambio ambiental; además, destaca los intereses en biopolítica de muchos escritos en este campo. A pesar de que un gran y aparentemente creciente número de autores en ecología política involucran el concepto de biopoder directamente -en sus formulaciones de acuerdo a Foucault, Agamben y otros-, escritos recientes de académicos en humanidades y ciencias sociales que utilizan explícitamente un lente biopolítico, proveen de una variedad de conceptos y preguntas de investigación que pueden enriquecer escritos de la ecología política. En la búsqueda por ampliar el diálogo entre académicos de biopolítica, ecología política, y dentro de ambos, este artículo explora nuevos y cambiantes contornos de las diferentes formas en que las ecologías políticas contemporáneas nos obligan cada vez más, a presentar las vidas de varias poblaciones humanas y no humanas, como Foucault planteó alguna vez, "en el dominio de cálculos explícitos." De este modo, 'nuevas fronteras' de investigación biopolítica son examinadas en relación a: i) especies, variedades, o 'múltiples modos' de gubernamentalidad y biopoder; ii) infraestructura (ecosistémica) crítica, riesgo, y biopolíticas 'reflexivas'; iii) historia ambiental, colonialismo, y las genealogías del biopoder, y iv) la proliferación de neologismos relacionados, tales como ontopoder y geontopoder.

Palabras clave: ecología política, biopoder, conservación, cambio ambiental, Foucault

\section{Introduction: what do we talk about when we talk about (bio)power?}

"If there is a political ecology", writes Paul Robbins (2012: 14), "by implication there must be an apolitical one." Construed in this way, political ecology is distinguished from comparatively managerialist or technocratic approaches to the study of ecological phenomena precisely because of its explicit attention to issues of power and asymmetrical power relations. Yet only rarely have political ecologists examined the concept of power itself, frequently operating with a perhaps intuitive but not explicitly defined version of the concept (Svarstad et al. 2018). In some ways, this is simply pragmatic, and possibly suggests an aversion within the field to the kind of "arid theorising" (Bryant and Goodman 2008: 710) or "definitional Olympics" (Naidoo 2016) that might appear to have little bearing on the everyday consequences of environmental change processes or interventions for a wide range of vulnerable populations. Conversely, however, the case can be made that a lack of specificity when it comes to the discussion of power and power relations in political ecology is potentially constraining. In other words, if we do not clarify 'what we are talking about when we talk about power', we risk limiting both the sophistication of our analyses, as well as our capacity to recommend or even conceive of actionable responses to the kinds of inequality and injustice that studies in political ecology regularly identify.

Here, I do not mean at all to suggest that political ecologists should attempt to somehow establish 'once and for all' - in a kind of pseudo-positivist mode - what power is or is not. Rather, I take a methodological cue from the introductory lecture of Michel Foucault's (2007: 16) Security, territory, population course at the Collège de France. Interestingly, and somewhat in contrast to the received wisdom that one occasionally encounters about the orientation of these lectures, Foucault (2007: 16) immediately announces quite bluntly at the beginning of the course that his goal "is not in any way a general theory of what power is." Indeed, as he puts it, his work

...is not a part or even the start of such a theory [...] this analysis could and would only be at most a beginning of a theory, not of a theory of what power is, but simply of power in terms of the set of mechanisms and procedures that have the role or function and theme, even when they are unsuccessful, of securing power. (Foucault 2007: 16-17)

This position was again later reiterated - in a rare essay originally drafted partly in English rather than French - where Foucault maintains that "the goal of my work during the last twenty years [...] has not been to analyze the phenomena of power, nor to elaborate the foundations of such an analysis" (1982: 777). Rather, Foucault instead declares that his project is oriented towards examining "the set of these mechanisms of power and to identify what is specific about them at a given moment, for a given period, in a given field" (2007: 17, emphasis 
added). His focus, in other words, was not on producing some sort of definitive or universal statement of the ontology of power - of what it is in timeless, absolute terms - but rather an historically contextualized account of what we might call its "technologies" or "mechanisms" of its operation (see also Collier 2009). Differently put, the goal was not to define power, nor to dictate the ways in which it should operate in accordance with a normative set of presumably 'legitimate' conditions (Fraser 1981), but to contribute to a richer understanding of how it is harnessed, wielded, or attained in particular historical and (though more implicitly) geographical contexts.

In short, the goal of this article is to review the operations of one such mechanism of power within recent writings in the field of political ecology, namely, what Foucault describes at the outset of the very same Security, territory, population course as "something that I have called, somewhat vaguely, bio-power" (2007: 16). Outlined most clearly at the end of the preceding Society must be defended lecture series (Foucault 2003) and in an essay appended to the first volume of The history of sexuality (Foucault 1978), the concept represents something of an underdeveloped thread in Foucault's broader oeuvre. Although he promises to pursue the topic as a central theme in both the Security, territory, population lectures and in the subsequent, misleadinglyentitled Birth of biopolitics course (Foucault 2008), both lecture series would ultimately have little to say about the concepts of biopower or biopolitics as such. Likewise, subsequent volumes of The history of sexuality would turn to Foucault's late concern with Greco-Roman philosophy and history, 'the care of the self', and the politics of confession, truth-telling, and parrhesia ('free, frank speech') (Elden 2016; Philo 2012). In many ways, however, it is Foucault's partial - yet nonetheless deeply generative - set of reflections on these themes that has inspired many subsequent writers to further develop, extend, or reformulate the concept of biopower. To date, this has certainly been the case within philosophy and social theory (e.g. Agamben 1998, 2005; Esposito 2008; Hardt and Negri 2000, 2009; Massumi 2015; Mbembe 2003; Povinelli 2016), but increasingly also within political ecology and related fields (e.g. Braun 2011; Büscher 2015, 2016; Carney 2014; Cavanagh 2014; Cupples 2012; Dalby 2013; Grove 2010; Nel 2015).

In undertaking this review, my intent is not to suggest that something called biopower has superseded or overshadowed other mechanisms and relations of power, nor is it to imply that we are witnessing a kind of epochal transition from an era characterized by sovereign or disciplinary power to one increasingly characterized by the more nebulous operations of biopower. Rather, it's more specific intent is two-fold: first, to review and highlight the ways in which a large and growing number of geographers and political ecologists engage the concept of biopower directly, albeit in a manner that has been adapted to prevailing "more than human" concerns related to both global and local forms of environmental change (e.g. Baldwin 2013; Cavanagh 2014; Dalby 2013). Secondly, however, I also highlight how a selection of recent writings across the humanities and social sciences by scholars explicitly engaging biopolitical concepts provide us with an array of provocative theorizations and research questions that may further enrich political ecology research (e.g. Massumi 2015; Povinelli 2016).

In pursuing these aims, the article proceeds as follows. First, I provide a definition and contextualization of the concept of biopower as it first appeared in the writings and lectures of Michel Foucault (e.g. 1978, 2003, 2007, 2008), with a particular focus on the environmental or even ecological dimensions of his reflections on this theme. Secondly, I explore the ways in which these writings have been explicitly harnessed by political ecologists to date, as well as how other recent contributions seem to implicitly engage the substance of these debates. Finally, I survey a selection of new frontiers emerging in what we might call 'biopolitical inquiry', and conclude with a discussion of the ways in which political ecologists might productively engage with or put these to use.

\section{Biopolitics (whatever that is...)}

"It is perhaps comforting", writes David Harvey in a recent book, "to explain away the recent stresses within capital as if we are confronting the birth pangs of an entirely new capitalist order in which knowledge and culture (and biopolitics, whatever that is) are the primary products rather than things" (2014: 238). The target of Harvey's ire, here, appears to be a particular strand of the continuously expanding literature in the humanities and social sciences on biopower and biopolitics. Specifically, one that arises from the work of 
Michael Hardt and Antonio Negri (e.g. 2000, 2009), who attempt to relate Foucault's original concerns to the political-economic crises of late capitalism.

In this sense, Harvey's confusion is understandable. Indeed, what was most explicitly and concisely formulated in a series of somewhat under-developed remarks at the end of Foucault's 1975-1976 lecture series at the Collège de France has since precipitated a secondary literature so large and diverse that it threatens to evolve into a field of study in its own right. In addition to Hardt and Negri's (2000, 2009) extension - and partial reformulation - of Foucault's writings on these themes, scholars of biopolitics can now engage a variety of alternative and sometimes contending accounts of the concept, such as those arising from the work of Giorgio Agamben (1998, 2005), Roberto Esposito (2008), Achille Mbembe (2003), Nicholas Rose (2009), Brian Massumi (2015), and Elizabeth Povinelli (2016). Perhaps as a consequence, the broader literature now includes a range of course companion-friendly readers and overviews of essential texts (e.g. Campbell and Sitze 2013; Lemke 2011), as well as that gold-standard indicator of academic subfield formation, namely the publication of The Routledge handbook of biopolitics (Rentea 2017). In addition, no fewer than two recent books have declared their intention to go "beyond biopolitics" in the titles of their respective volumes (Clough and Willse 2011; Debrix and Barder 2012). Review articles also now abound that aim to situate distinct versions of the concept of in relation to geography (Rutherford and Rutherford 2013a, 2013b; Schlosser 2008; Srinivasan 2017a), political geography (Coleman and Grove 2009; Minca 2015), development studies (Cavanagh 2014), and 'critical environmental politics' more specifically (Grove 2014a), though somewhat curiously not in relation to political ecology as a field per se. While many political ecologists will be familiar with Foucault's writings on these themes, it is perhaps worthwhile - particularly in light of Harvey's apparent consternation above - to first briefly revisit the general sweep of his argument (see also Collier 2009; Elden 2016; Philo 2012).

\section{Contours of biopower: population, regulation, and the milieu}

Discussions about Foucault's ostensible 'view of power' are often complicated by the diversity of his writings on this topic, as well as the ways in which his writing and thinking on power and its relationship to subject formation evolved over time (e.g. Foucault 1982). Given that Foucauldian theory has been standard fare in Anglophone doctoral training programs in the humanities and social sciences for at least three decades, it is perhaps the case - to some degree - that the historical moment of one's graduate training might reflect the aspects of Foucault's writings on power, knowledge, and discourse that one is most likely to be familiar with. Indeed, this is somewhat unavoidable given that Foucault has continued to 'publish', at least in the form of previously unavailable English translations, through the last several decades and to date (e.g. Foucault, 2017; Foucault 2018).

In relation to biopower, in particular, Foucault (1978: 136-137) famously defines the concept by way of a juxtaposition: in relation to "sovereign power", or the power to "take life or let live", bio-power is construed as the power to "make live or let die." At first, this might seem like an overly narrow distinction - and indeed, as we will see, the instances in which this first mechanism of power appear to intersect with the second have continued to provoke considerable debate amongst theorists of biopolitics (see, especially, Agamben 1998; Esposito 2008; Mbembe 2003). Nonetheless, by juxtaposing these two concepts, Foucault is able to unearth a suite of previously rather neglected research questions, or at least to approach certain old questions in novel ways.

In short, this notion of biopower refers to the ways in which, from the eighteenth century onward in Europe, 'the population' - and especially the health and well-being of the population - apparently emerges more centrally than before as an object of scientific measurement and government more broadly. Here, the emergence of demography, public health, and what we now term 'the social sciences' constitute quintessential examples, inherently concerned with the quality of various populations and opportunities for their improvement. Moreover, these new disciplines and forms of knowledge would become increasingly inextricable from the implicitly political regulation and management of human individuals and communities. In other words, what gradually becomes clear is that each of these disciplines, or forms of "power-knowledge" (Foucault 1980), were not simply descriptive. Rather, they would also produce a normative vision for how both individuals and populations should behave. 
Here, examples might include the 'truck, barter, and trading' individual imagined by Adam Smith and other liberal economists, to the ideally hygienic and non-promiscuous citizen propounded by medicine and public health, to the fastidious and punctual worker demanded by early industrial capital and the forms of labor administration to which it gave rise. For Foucault, this growing awareness of the political utility of the regulation rather than the merely threatened cessation of life thus manifests in two inter-related forms: first, in a disciplinary power or "anatamo-politics" of individual bodies, and, secondly, a "biopolitics" of the population more broadly. Within the relationship between the two, of course, we find the foundation of Foucault's late interest in sex and sexuality, as it is in the regulation of sex that the disciplining of individual bodies transmutes into the management of reproduction and therefore of the population itself (e.g. 1978).

It is often remarked that Foucault's writings on biopower contain few explicit linkages with environmental concerns. Lorimer (2015: 13), for instance, contends that "Foucault is resolutely human in the foci of his analyses of biopower and notoriously ambivalent about animals and the environment as political problems." While it is true that the environment as such is far from a central theme in these texts, neither is it totally absent per se. Interestingly for political ecologists, Foucault indeed highlights certain ways in which biopolitical forms of knowledge and governance came to perceive the environment and environmental problems as a central object of concern, even if indirectly. Here, the underlying governance issue is "the sudden emergence of the problem of the 'naturalness' of the human species within an artificial milieu", and in which:

The sovereign deals with a nature, or rather with the perpetual conjunction, the perpetual intrication [sic] of a geographical, climatic, and physical milieu with the human species [...] the sovereign will be someone who will have to exercise power at that point of connection where nature, in the sense of physical elements, interferes with nature in the sense of the nature of the human species, at that point of articulation where the milieu becomes the determining factor of nature. This is where the sovereign will have to intervene, and if he wants to change the human species [...] it will be by acting on the milieu. (Foucault 2007: 38)

Particularly in Foucault's (2007) writings on the concept of the milieu, we find a decidedly sophisticated account of human-environment relations, one in which both 'natures' and 'human natures' are co-produced through the practice of government. In what follows, I turn to the growing ways in which recent writings within political ecology have explicitly engaged with the concept of biopower as it has been formulated in the above, highly suggestive writings by Foucault. As we will see, these studies certainly illuminate the implicitly biopolitical stakes of both emerging and evolving forms of governmentality in the context of both local and global processes of environmental change.

\section{Political ecologies of biopower: population, "green governmentality", and the global milieu}

Over the last few decades, there has been a well-documented explosion of Foucaultian scholarship within and beyond Anglophone studies, to the extent that - based on Web of Science and Google Scholar data - Michel Foucault is often ranked as the most cited scholar in the humanities and social sciences (e.g. Thompson Reuters 2009). This has certainly been the case not least within geography and anthropology, which are perhaps the two most readily identifiable disciplinary 'parents' of contemporary political ecology. More strikingly, however, Foucault is now also amongst the most cited individuals indexed by Google Scholar overall, regardless of discipline or field of study, and whether measured by h-index or total citation count (e.g. Webometrics 2016). By the rough indication of Google's Ngram viewer, for instance, the scale of this literature is such that references to 'governmentality' now substantially outstrip those to 'political ecology', whereas the terms 'biopower' and 'political ecology' were approaching quite comparable (case-insensitive) prevalence as of the limit of Ngram's currently available dataset in 2008 (Figure 1). 


\section{Google Books Ngram Viewer}
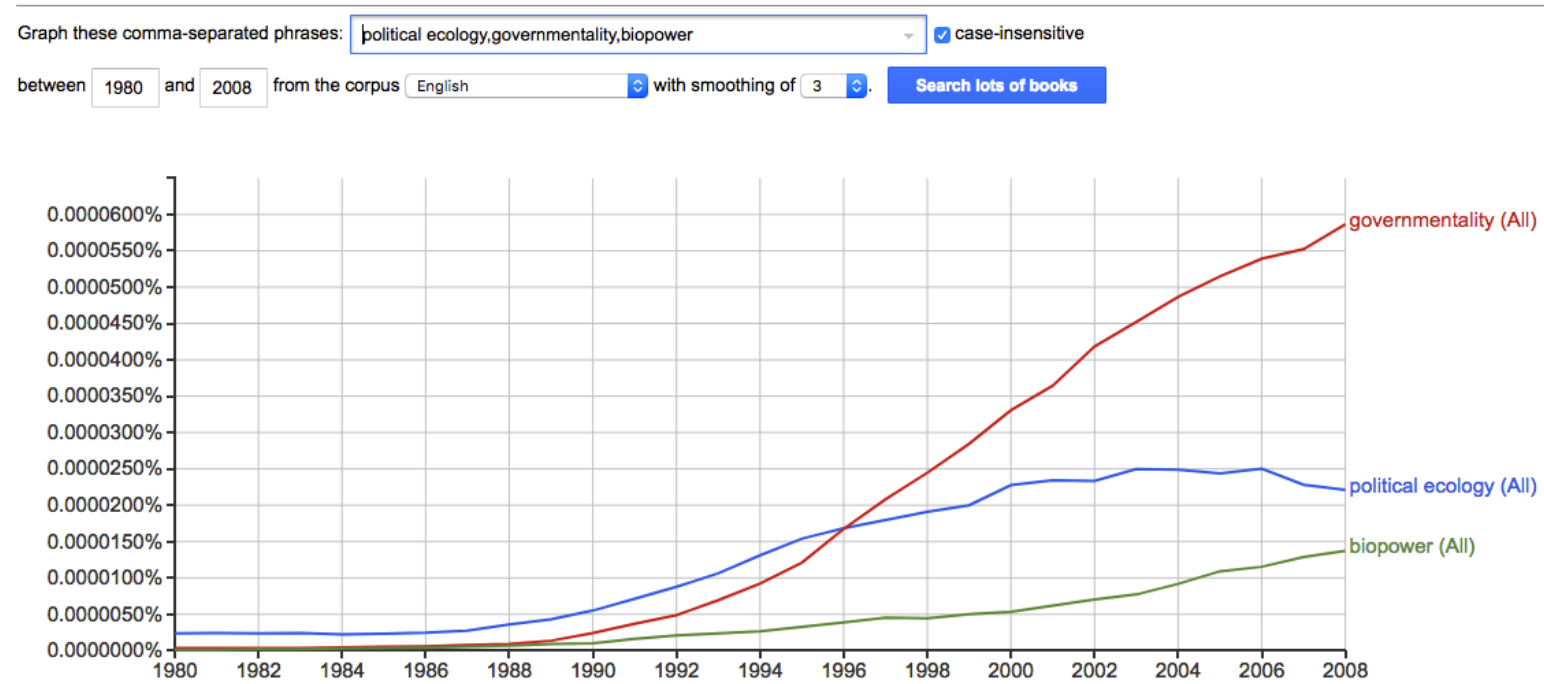

Figure 1: Google Ngram view of key terms (political ecology, governmentality, and biopower), 1980-2008. Though a rough measure, Google Ngram remains useful for displaying the relative prevalence of selected key terms in the Google Books database (shown as a percentage, along the vertical axis) over time. The currently available database searches entries made available until the year 2008. See http://books.google.com/ngrams (accessed 10 September 2018), and Michel et al. (2011) for details about the underlying dataset.

Until quite recently, Foucaultian scholarship within political ecology and related fields has tended to reflect this disproportionate focus on governmentality rather than biopower per se. For instance, Anglophone efforts to relate Foucault's concept of governmentality to issues and practices of environmental management began to emerge in the mid-1990s, leading to concepts such as "environmental governmentality" (Darier 1996), "environmentality" (Luke 1995), "green governmentality" (Luke 1999; Watts 2002), and "ecogovernmentality" (Goldman 2001). ${ }^{2}$ Moreover, interest in these themes has so far sustained a second - and perhaps even a nascent third - generation of scholarship utilizing these concepts. This includes renewed theorizations of environmentality (Agrawal 2005) and its neoliberal or other varieties (Fletcher 2010, 2017), green governmentality (Rutherford 2007; Wang 2015), eco-governmentality (Malette 2009; Valdiva 2015), and earth system governmentality (Lövbrand et al. 2009). Ever-more specific iterations of these concepts have also been forthcoming, including those related to "groundwater governmentality" (Birkenholtz 2009), "climate governmentality" (Death 2013), "forest governmentality" (Bose et al. 2012), and even Reducing Emissions from Deforestation and Forest Degradation or "REDD+ governmentality" (Astuti and McGregor 2015).

In part, this early focus on governmentality in particular, may reflects a late resurgence of interest in the concept of biopower following the English-language publication of the Society must be defended lectures in 2003, as well as the rise to prominence of Giorgio Agamben's $(1998,2005)$ influential critique of Foucault's writings on this topic in the early 2000s (see for example, Ek 2006). Indeed, as Elden (2002: 126) notes, Foucault himself lamented in a 1977 interview that his essay on biopower in The history of sexuality (initially published in French in 1976) seemed to be under-appreciated. By contrast, an English translation of Foucault's now most well-known 'governmentality' lecture in the Security, territory, population course (Foucault 2007)

${ }^{2}$ Discussions of Foucault's concept of governmentality in relation to empirical research in political ecology were also widespread throughout the 1990s and early 2000s. The size of this literature is such that it precludes a thorough review here. For early examples, see Braun (2000), Brosius (1999), Li (1999), Moore (1999) and Sivaramakrishnan (1999). More recent empirical engagements include Dressler (2014), Kolås (2014) and Yeh (2005). 
had been available following its publication in the journal Ideology and consciousness in the late 1970s (see Foucault 1979). However, circulation of the piece increased dramatically after its inclusion in Burchell et al.'s (1991) edited volume entitled The Foucault effect: studies in governmentality (see Foucault 1991). That said, the full course in which this 'governmentality' lecture was embedded was not fully available in English until 2007, perhaps limiting a fully contextualized understanding of Foucault's notion of governmentality, as well as its relation to his previous writings and lecture courses.

Even within this literature on 'green' governmentality, however, explicit engagement with the concept of biopower has often been fleeting, and occasionally non-existent. Aside from early reflections by Paul Rutherford (1993, 1999), much of the 'first generation' literature on 'green' or 'eco' governmentality makes scant reference to the concept. For instance, even in Luke's (1995: 95) early account of the concept of environmentality, Foucault's genealogy of biopower in The history of sexuality is reconstructed as being "not historically closely focused upon the role of Nature in the equations of biopolitics." Likewise, in Goldman's (2001: 502-503) much-cited article - which was later reprinted in the second edition of Peet and Watts' Liberation ecologies (2004) - the concept of biopower is framed primarily as a means of shaping the values and subjectivities of various human populations, rather than as a means of bridging the concerns of effectively governing human and nonhuman forms of life. Even in more recent theorizations of 'green governmentality', the nonhuman dimensions or implications of biopower in Foucault's writings are often downplayed, with Stephanie Rutherford (2007: 294) - for instance - suggesting that "[n]ature was never high on Foucault's list of priorities - in fact, he indicated a definite distaste for it." In still other accounts, the concepts of biopower and biopolitics do not appear whatsoever (e.g. Luke 2009).

Aside from the simple availability of certain texts, the apparent privilege afforded to issues of governmentality rather than biopower perhaps signals a (mis)conception that the progression of Foucault's work evinces a gradual abandonment of questions of 'power' as such in favor of an analysis of government, governmentality, and subjectivity (e.g. Oels 2005). And yet, as the editor of the Security, territory, population lectures - Michel Senellart (2007: 495) - puts it:

The analytical perspective of 'governmentality' is not therefore a break in Foucault's work with regard to his earlier analysis of power, but is inserted within the space opened up by the problem of bio-power. So it would not be accurate to claim that from this time the concept of 'government' replaces that of 'power,' as if the latter now belonged to an outmoded problematic. The shift from 'power' to 'government' carried out in the 1978 lectures does not result from the methodological framework being called into question, but from its extension to a new object, the state, which did not have a place in the analysis of the disciplines.

At issue, in other words, was not so much a superseding of Foucault's interest in various forms of power by a more 'refined' or complex understanding of governmentality. Rather, these lectures in many ways constitute an exploration of how the forms of knowledge produced by various disciplines became translated into practices and mechanisms of governing both individuals and populations. In other words, an exploration of how different forms of power are in fact wielded or deployed in the practice of government.

Indeed, a more recent wave of scholarship in political ecology and related fields has sought to engage the concept of biopower directly, in precisely such terms. That is, as one amongst several forms of power that can be deployed under a wide range of distinct constellations of governance or governmentality, but also as a form of power that is deeply concerned with the regulation of nonhuman environments and populations as well. As numerous scholars have pointed out, such concerns are increasingly salient in relation to processes of regional and global environmental change, the effects of which retain deeply biopolitical consequences for a wide range of vulnerable populations (e.g. Baldwin 2013; Cavanagh 2014; Dalby 2013; Grove 2010).

It is indeed the case that Foucault's own reflections about such environmental dimensions of biopolitics were far from systematic. But, as Dillon and Lobo-Guerrero (2008) remind us, governmental concern with the exercise of biopower will always to some degree be "recombinant" with the contingencies of any given historical and geographical context. That is to say, the "art of government" (e.g. Foucault 2007: 110) inevitably 
engages an empirical context or milieu that is dynamic rather than static, and where challenges to both the security and prosperity of favored populations are sometimes clear and present, but more frequently "emergent" or only in the process of coming into being (see also Braun 2011). It follows that - regardless of the specific problems that Foucault $(1978,2003)$ identified as being at the 'root' of the emergence of biopolitical forms of government in the eighteenth century - these concerns will inevitably evolve and mutate as do the empirical contexts within which states, governments, and other actors engage. Very simply put, the process of "[w]estern man [...] gradually learning what it meant to be a living species in a living world" (Foucault 1978: 142) is far from over, and today manifests as an unprecedented awareness of the ways in which contemporary forms of economic development and socio-political organization increasingly threaten the environmental bases of human prosperity, demanding new or intensified forms of regulation and management. In relation to this context, as Biermann and Mansfield (2014: 259) note, we indeed only "have an anemic understanding of biopower if we look only at human life."

In this regard, a growing number of geographers, anthropologists, and political ecologists have been sketching the empirical contours of contexts in which the contemporary exercise of biopower demands that both human and nonhuman populations be brought "into the realm of explicit calculations" (Foucault 1978: 143). Cavanagh (2014: 277), for instance, re-reads Foucault's writings on biopolitics alongside those of Giorgio Agamben and other theorists, arguing that - under conditions of global environmental change - "biopolitics mutates from simply constituting a specific mode of governing humans, if it ever truly was, and instead manifests as the politics and political economy of supporting certain and asymmetrically valued forms of both human and nonhuman lives within rapidly shifting ecological conditions." In a similar vein, Grove (2010) examines new forms of "disaster" insurance within sustainable development projects as inherently biopolitical technologies, oriented towards distributing risk, extending protection to certain favored segments of the global population, and enhancing their capacity to endure through increasingly prevalent socio-ecological shocks and calamities. Further still, Baldwin (2013: 60) takes up an analysis specifically of the global carbon cycle itself as an object of biopolitical governance, noting the ways in which the exercise of biopower in this context is "precisely about allowing for rather than inhibiting the complex adaptation of socio-ecological systems as a means of achieving their resilience in the contingent context of climate change." Likewise, Simon Dalby (2013) links these and similar debates to related discussions about "the Anthropocene" as a geological era defined by the consequences of human activity. Dalby traces how eighteenth century concerns about the welfare of human "populations" have evolved into a more systemic problematic of securing the conditions of sustainable prosperity for what Reid (2010) terms "biohumanity", or humanity understood as a species inextricably embedded within complex biological and ecological systems (Dalby 2013: 185).

Though these analyses of biopower in relation to global environmental change have tended towards the large-scale and the abstract, a parallel group of contributions specifically on the biopolitics of forest and biodiversity conservation has grown steadily (e.g. Biermann and Anderson 2017), and generated increasingly fine-grained empirical analyses. Here, as Biermann and Mansfield (2014: 258) put it, biodiversity conservation can be understood as a form of biopolitics in the sense that it "emphasizes distinctions between biological kinds and develops interventions based on these distinctions - a logic that also informs racial, biological distinctions among humans." Building upon this insight, others have sought to map the varied ways in which the marking of such 'distinctions between biological kinds' by conservation biologists intersects with the differential racialization and subsequent treatment of certain human populations. Cavanagh and Benjaminsen (2015), for instance, adopt an explicitly biopolitical approach in examining the ways in which international support for forest conservation at Mount Elgon National Park in Uganda has de facto resulted in the preservation of certain types of flora and fauna in ways that have entailed the quite violent dispossession of historically raced and marginalized groups of agriculturalists and agro-pastoralists in the region. Likewise in Uganda, Nel (2015) suggests that contemporary forms of neoliberalized conservation in the country have given rise to both "direct" and "circuitous" forms of biopolitics. In this reading, the biopolitics of conservation entails the "sacrifice" both of human communities and customary forms of environmental stewardship, as well as formerly protected ecosystems that are now thought unlikely to "pay their way" under an increasingly neoliberalized regime of conservation governance. 
Still other writers have sought to enrich our understanding of the biopolitics of conservation by attempting to break with the "anthropocentrism" or even "species chauvinism" (Haraway 2008: 60) that is often said to characterize Foucault's writings. Here, numerous contributions have stressed the "more-than-human" (Cavanagh 2014), "posthuman" (Cadman 2009), or "cosmopolitical" (Lorimer 2015: 3-4) dimensions of contemporary biopower, seeking to extend "the scope of biopolitics to the realm of governing [the] nonhuman" (Braverman 2015: 13). A strand of this literature in geography and political ecology has evolved in tandem with a related one in the humanities, including works at the intersection of "animal studies" and "biopolitical studies" by Shukin (2009), Chrulew (2011), Smith (2011), Wolfe (2013) and others. In their analysis of "bovine biopolitics" in the Netherlands, for instance, Lorimer and Driessen (2013: 257) demonstrate how practices of "rewilding" are a growing facet of contemporary "cattle governance", suggesting that "animal geographies in particular, have a lot to gain from exploring biopolitics as multiple modes of living with nonhuman life, rather than solely as the control over nonhuman life." Hodgetts (2017) likewise extends this focus on the multiplicity of more-than-human biopolitics, pointing out the ways in which diverse conservation interventions might be characterized by either eco-centric or anthropocentric approaches to the governance of flora and fauna, and with divergent both political and ecological effects. In a similar vein, Srinivasan's writings on the biopolitics of conservation and animal welfare regulations encourage us to perceive nonhuman lives themselves as a possible target for what Foucault once termed strategies of "subjectification", or the subtle shaping of individual desires for particular subjectivities, self-care, and improvement (2013, 2014, 2017b). Often grounded in careful ethnographic work, empirically-oriented studies have now drawn upon the concept of biopolitics to examine the governance of similar human "entanglements" with various species and ecosystems, including cougars (Collard 2012), Canadian temperate rainforests (Braun 2002), invasive species such as "chestnut blight" (Biermann 2016), and even the concept of biodiversity itself (Dempsey 2016).

Beyond the conservation of species and ostensibly 'natural' ecosystems, political ecologists also continue to extend biopolitical analyses to other dimensions of environmental and natural resource governance. For instance, examining the role of the World Bank in 'public water' development schemes, Bakker (2013: 282) writes that "[w]ater is thus biopolitical in the Foucauldian sense: modern governments seek to optimize both water resources and our individual water use practices in order to secure the health and productivity of the population." These concerns are likewise reflected in Hellberg's (2014) scholarship on the governance of urban water supplies in South Africa, noting the ways in which contemporary inequalities in access to potable water continue to reflect the deep biopolitical caesuras forcibly inscribed upon the South African population by the apartheid state. Surveying these and similar contributions, Rattu and Véron (2016) make the case for a specifically "Foucaultian urban political ecology" that would explicitly seek to complement Marxist approaches to uneven development and the production of (urban) natures with a conceptual apparatus grounded in Foucault's theorization of biopolitics and governmentality.

Other contributions have continued to emerge in such volume and with such scope that they defy straightforward categorization. These include analyses of famine (Nally 2008) and contemporary food security (Carney 2014; Nally 2011), as well as global health and the proliferation of well-known and "emerging" infectious diseases (e.g. Braun 2011; Mansfield 2012; Rabinow and Rose 2001). The latter now include examinations of the "microbial biopolitics" even of specific diseases or pathogens, including malaria (Evered and Evered 2012), HIV/AIDS (Comaroff 2007; Giami and Perry 2012), and the "conditions of emergence" for new strains, for instance, of avian influenza (Braun 2011). These inquiries into food and "bio" security also increasingly dovetail into studies of the biopolitics of security and development (e.g. Dillon and Lobo-Guerrero 2008; Duffield 2007). This is particularly the case as the distinction becomes increasingly blurred between justifications for security interventions in the interest of "human" as opposed to "environmental" or biological health and well-being (see, for example, Reid 2010, 2013). Such concerns are certainly visible, for example, in the apparent "militarization" or "securitization" of conservation (Kelly and Ybarra 2016; Loperena 2016; Lunstrum 2014), forest governance (Cavanagh et al. 2015), and even climate change adaptation and mitigation activities (Dunlap and Fairhead 2014; Reid 2014). The most ominous examples of this today are the forms of gene-editing technologies - such as CRISPR-Cas9 (Hsu et al. 2014) - being proposed as a means of eradicating 'problematic' vector, invasive, or disease-bearing species, and in which the US military is currently investing heavily (see Nelsen 2017). Though perhaps effective in the control of ostensibly undesirable forms of nonhuman 
life, the second and third-order ecological implications of such technologies are of course potentially ruinous for humans and other nonhuman species alike.

Though the primarily empirical studies reviewed above are as diverse as they are illuminating, they have also been paralleled by a substantial body of theoretical or even philosophical work that has sought to critique, reformulate, or even advocate for the abandonment of Foucault's concepts of biopolitics and biopower altogether. Hence, in what follows, I turn to these 'new frontiers' of biopolitical inquiry, and point to the ways in which political ecologists might productively engage with this increasingly dynamic body of work as well.

\section{New frontiers of biopolitical inquiry}

\section{Toward species, varieties, or 'multiple modes' of governmentality and biopower?}

Particularly in the Security, territory, population lecture series, Foucault's reflections situate the concept of biopower and the biopolitics of both population and environmental management within a "triangle" of technologies, mechanisms, or 'forms' of modern power that also includes its sovereign and disciplinary manifestations (e.g. 2007: 107-108). As Foucault is frequently at pains to assert, however, these concepts are not mutually exclusive, and neither is the relationship between them hard and fixed. Rather, the precise constellation of these forms of power that is deployed in any given time and place is inevitably contingent upon specific historical and geographical contexts or conditions. Consequently, as Moore (2005: 7, emphasis original) puts it, this "triangle" of powers "does not make for a stable tripod, but rather constitutes a triad in motion", one that draws our attention to "shifting alignments" and "contingent constellations of power" more so than its ostensibly universal or inexorable machinations. Povinelli has recently made much the same observation, writing that "all three formations of power are always copresent, although how they are arranged and expressed relative to each other vary across social time and space" (2016: 6).

Although Foucault's explicit remarks about the relationship between what he terms "governmentality" and these forms of power are ultimately few, one might infer that it is their variable deployment or "contingent constellation" in distinct empirical settings that ultimately characterizes the prevailing form of governmentality at work (see also Cavanagh and Benjaminsen 2017; Fletcher 2010, 2017). As Collier (2009: 98-99) rightfully argues, the concept of governmentality "is prone to reification, as though it were a coherent regime that dominated an epoch [...] In a strict sense, governmentality designates the genus - diagrams of political rationality, 'govern-mentalities' - of which specific political rationalities, such as advanced liberalism, are species." In the Birth of biopolitics lectures, for example, Foucault himself cautions against tendencies towards such generalist or "inflationary" analyses that would presume to identify the overall character of power or government in a given epoch or historical period, after which it might be assumed that "there is no longer any need to analyze [empirical] actuality" (2008: 188). In this sense, the relative presence or absence of the forms of power discussed above do not constitute some sort of an irreducible typology: they are simply a model of sorts that helps us to begin identifying or characterizing the 'species' of power or governmentality that is the subject of empirical scrutiny within the parameters of any given study.

Accordingly, a number of scholars have recently suggested possibilities for disaggregating the notion of governmentality as it pertains to the environment - or environmentality, for short. In turn, this also raises corresponding implications for how we might conceive of the operations of biopower within the 'varieties' or 'modes' of governmentality or environmentality that result (e.g. Bluwstein 2017; Fletcher 2010; Youdelis 2013). In a recent intervention, for instance, Rob Fletcher observes that "a useful direction for future research" would be to investigate the potentially intersecting existence of "multiple environmentalities", as well as "to explore the varieties of biopower these advocate as well" (2017: 4).

Building upon a previous contribution (Fletcher 2010), Fletcher (2017: 2) draws upon a reading of Foucault's The birth of biopolitics lectures in particular to suggest that we might productively distinguish between sovereign, disciplinary, neoliberal, and 'truth' environmentalities, each of which might present us with empirical nuances in their respective deployments of biopower. This is surely an important observation, and a crucial area for future research in political ecology and related fields. The question remains, however, whether or not the generation of such typologies might in fact fall within the purview of Foucault's critique of 
"inflationary" analyses mentioned above. That is to say, one emerging topic for discussion and debate concerns the empirical validity, status, or even 'ontology' of such typologies: in other words, whether it might simply suffice to say that any given form of governmentality, environmentality, or biopower is constituted in historicalgeographical context, and therefore must be empirically and inductively analyzed on that basis. Regardless and as per Foucault's remark above - it seems pertinent to reiterate that the development of such typologies of environmentality or biopower should not come at the expense of 'efforts to analyze empirical actuality', the messiness of which may occasionally elude tidy categorization even in the form of apparently intersecting 'multiple environmentalities.'

\section{Critical (ecosystem) infrastructure, risk, and 'reflexive' biopolitics}

Another strand of this emerging literature is distinguished by its connection of Foucault's work on biopolitics with 'modern' concerns related to critical public infrastructures, complex systems, and anthropogenic or human-engendered forms of risk. Collier and Lakoff, for instance, have recently elaborated upon what they term 'vital systems security', or a form of security that they argue has emerged only since the middle of the twentieth century, and as a novel mutation of what Foucault once termed 'biopolitics' (2008, 2015). This novel form of biopolitics is one that is primarily concerned not with measuring and influencing the well-being of the population directly, but with the security of various forms of vital infrastructure - communications, defense, provisioning, transportation, and so forth - whose effective functioning constitutes a necessary precondition of such well-being.

In this account, these vital systems begin to emerge as an integral object of governance in the twentieth century's interwar period - and particularly the Great Depression - as 'the economy' was increasingly seen as a distinct system whose satisfactory machinations were essential not simply for prosperity, but also for the security of the state and its population as such (see also Mitchell 1998). In turn, Collier and Lakoff (2015) argue that these concerns were amplified in the Second World War and the Cold War, during which various 'critical' infrastructures emerged as objects - or, more specifically, targets - of military strategy. Particularly in the context of the Cold War and the potential for nuclear deployment, the focus of state security strategy begins to shift, from the prevention of disorder as such, or the insulation of vital systems from it, to the various possibilities for ensuring the functioning of vital infrastructure through disorder.

As a corollary, this leads Collier and Lakoff (2015: 21-22) to propose the related concept of "reflexive biopolitics", which aims to ensure the security and well-being of the population not only in abstract general terms, but specifically in relation to the new forms of risk and possible catastrophe engendered by modern forms of governance and economic development themselves. This conceptualization exhibits clear undertones of inspiration from Ulrich Beck's work on risk and 'risk society' (2012) - as well as, perhaps, the much older work of Theodor Adorno and Max Horkheimer (2002 [1944]) in Dialectic of Enlightenment - which highlights the salience of previously unforeseen risks related to the introduction new forms of economic and technological development. In other words, a 'reflexive biopolitics' in this context is one concerned with the protection of populations and infrastructures against threats that are in some sense 'emergent' from or arising as the sideeffects of prevailing forms of politics, economics, and governance.

Beck's later work on the sociology of risk was preoccupied with ominous environmental risks that are nonetheless anthropogenic in nature (e.g. 2008: 81-85). Particularly, those related to climactic and other forms of environmental change. Unsurprisingly, geographers and political ecologists are contributing to the extension and refinement of Collier and Lakoff's (2015) work in this regard, pointing to the ways in which ecosystems and other biophysical processes might themselves be conceived as a form of 'vital' infrastructure or security concern (e.g. Hinchliffe and Bingham 2008; Grove 2014b). For instance, Baldwin (2013) usefully theorizes contemporary attempts to govern the global carbon cycle as a form of "vital ecosystem security." Here, biopolitics is understood both in terms of the protection of such ecosystem infrastructures from degradation and risk, as well as the inculcation of norms and values related to good "environmental citizenship" within both individuals and populations as a means of pre-empting further ecological calamity.

Beyond the carbon cycle, however, the extension of Collier and Lakoff's work on reflexive biopolitics to environmental concerns would also appear to bear deep relevance for the analysis of emerging "discourses 
of truth" related to global environmental governance. Indeed, one could argue that Rockström et al.'s (2009) conceptualization of "planetary boundaries" and "tipping points" in the functioning of various earth systems such as the carbon, nitrogen, and phosphorus cycles - as well as broader concerns related to biodiversity decline, freshwater depletion, and the acidification of the oceans clearly evince anxieties related to the security of different forms of "ecosystem infrastructure." Likewise recent proposals by these and related "sustainability scientists" to "guide human development" in ways that remain well within planetary boundaries entail a clearly reflexive biopolitics of precisely which populations will be most exposed to the costs and risks of doing so (see, for example, Steffen et al. 2015). Further still, the gene-editing and extinction technologies mentioned above are also a glaring example of our contemporary 'dialectic of Enlightenment' (Adorno and Horkheimer 2002 [1944]), insofar as they simultaneously promise to deliver us from short term ecological or epidemiological crises and threaten to catalyse even more serious ones through their second-order effects (e.g. Nelsen 2017). This interface of work related to reflexive biopolitics, ecosystem infrastructure, and anthropogenically-induced risk appears to be particularly amenable to further inquiry by political ecologists.

\section{Deepening, broadening, and provincializing genealogies of biopower}

A third source of considerable dynamism in conceptual engagements with Foucault's work on biopower concerns its historicization, or its contextualization within and between diverse historical and geographical conjunctures. Much of this work takes its cue from Giorgio Agamben's influential critique of Foucault's writings on both biopolitics (e.g. Agamben 1998, 2005) and governmentality (Agamben 2011). As Agamben (1998: 9) famously and cryptically argues:

The Foucauldian thesis will then have to be corrected or, at least, completed, in the sense that what characterizes modern politics is not so much the inclusion of zoe in the polis - which is, in itself, absolutely ancient - nor simply the fact that life as such becomes a principal object of the projections and calculations of State power. Instead the decisive fact is that, together with the process by which the exception everywhere becomes the rule, the realm of bare life - which is originally situated at the margins of the political order - gradually begins to coincide with the political realm, and exclusion and inclusion, outside and inside, bios and zoe, right and fact, enter into a zone of irreducible indistinction.

Here, utilizing Aristotle's classical distinction between bios (political life) and zoe ('bare' life), Agamben argues that - rather than arising in the eighteenth century - politics in the western world has in fact been "a biopolitics from the very beginning" (1998: 181). Admittedly, Foucault was very much familiar with Aristotle's writings on these themes, observing in The history of sexuality that "[f]or millennia, man remained what he was for Aristotle: a living animal [zoe] with the additional capacity for a political existence [bios]; modern man is an animal whose politics places his existence as a living being in question" (Foucault 1978: 143). Yet, re-reading Foucault's lectures on the biopolitics of Nazism and Stalinism in Society must be defended (e.g. 2003: 250-255), Agamben reformulates the notion of biopower as an always-present, converse dimension of sovereign power, and one that has been at work in the western world since antiquity. That is to say, biopower for Agamben is primarily the power to exclude, in a "state of exception", certain individuals or populations from the protections of the law, and to create a context in which death can be meted out - even, as in the case of Nazism, on a mass scale - without the crime of murder formally being committed.

Although Agamben's own writings on these themes have themselves been critiqued from a variety of perspectives (see, for example, Lemke 2005; Ojakangas 2005), his work has also led many to productively rethink Foucault's concept of biopolitics from a range of different historical-geographical contexts and perspectives. To date, this has primarily been the case in relation to various forms of European colonialism and settler colonialism (e.g. Bignall and Svirsky 2011; Morgensen 2011 Rifkin 2009; Stoler 1995), although Ojakangas (2016) has recently published an alternative genealogy of biopower and argued for its roots in Greek antiquity. The absence of a concern for the former colonial-empirical contexts in Foucault's work is somewhat curious; as Legg (2007) notes, Foucault had little to say about colonialism. This is despite his oft-quoted 
observation that many of the techniques of discipline and governmentality that concerned him had arisen in Europe as a result of a "boomerang effect" of their initial deployment in European colonies (e.g. Foucault 2003: 103). Consequently, a number of calls have emerged to "provincialize" Foucault's writings on biopower and governmentality (à la Chakrabarty 2009), or to illuminate the ways in which his sweeping account of biopolitical governance emerging for the first time in eighteenth-century Europe is perhaps poorly reflective or even simply ignorant of non-Western histories and experiences (see, especially, Cavanagh and Himmelfarb 2015; Legg 2007; Moore 2005; Povinelli 2016: 3-4).

Drawing substantially upon Agamben's writings and those of anti-colonial thinkers like Franz Fanon and Aimé Césaire, Achille Mbembe (2003) has sought to address this 'colonial' lacuna in Foucault's work on biopolitics. In his account, the operations of biopower under colonial rule on the African continent and elsewhere were less a straightforward exercise in 'making live or letting die' as they were a form of "necropolitics", enacted within a colony understood as a "terror formation" characterized by the "concatenation of biopower, the state of exception, and the state of siege" (Mbembe 2003: 22). Under such conditions, for Mbembe (2003: 24), "the colonies are the location par excellence where the controls and guarantees of judicial order can be suspended - the zone where the violence of the state of exception is deemed to operate in the service of 'civilization"' (Mbembe 2003: 24). In other words, diverse "civilizing missions" were certainly implemented in European colonies ostensibly in the interest of "improving" the lives and livelihoods of colonized populations. However, these initiatives were nonetheless enacted upon individuals and populations often thought to inhabit, in Mbembe's (2003: 26) terms, "a third zone between subjecthood and objecthood", or to be generally devoid of the same range of rights and protections that European citizens might have availed themselves of in the metropole. Perhaps the most obvious of these refusals to recognize 'native' rights are related to the subjugation of customary law and property under terra nullius or res nullius (unowned land or property) doctrines of various kinds, notwithstanding the fact that these manifested in empirically distinct ways in contexts as diverse as Australia, the United States, and Sub-Saharan Africa (Cavanagh and Himmelfarb 2015). Nonetheless, a common effect of these doctrines has been an enduring and more or less explicitly racialized dispossession of land and property, and even of legal personhood itself if one considers the involvement of early European empires in the trans-Atlantic slave trade.

In this sense, certain writings in political ecology and environmental history would seem to challenge Foucault's genealogy of the emergence of biopolitics in eighteenth-century Europe, though largely implicitly. As the work of the environmental historian Richard Grove showed, European concerns with the security of various types of ecological systems began to emerge as early as the seventeenth century in island colonies such as St. Helena and Mauritius (1996). Indeed, it was here that colonial officials first observed and studied in detail the relationships between deforestation, water catchments, and soil erosion. Yet these concerns were far from 'merely' academic - they were in fact driven by anxieties related to the sustainability of commercial agriculture and extractive industry in colonial 'possessions', as well as, by extension, the potential for colonies to be economically self-sustaining rather than draining metropolitan resources. In other words, these colonial administrations were very much preoccupied with what Foucault once termed "a sort of complex between men and things" (2007: 134). Hence, as Grove once put it,

...[i]t is a common fallacy to think that globalization and environmental crises are new phenomena, or products only of the post-World War II world [...] the story of environmentalist reactions to human-induced ecological changes on a global scale is actually more than three centuries old. (2002: 50)

While Foucault may have been perfectly correct to note the emergence of a particular sort of "environmental" concern with epidemiology and food security in the eighteenth century, European concerns related to vital ecological systems arguably evince a much longer historical pedigree in the colonial world, if not in Europe as well (Foucault 1978, 2003).

Though not always concerned with the health and well-being of colonized subjects, per se, these logics and technologies of colonial governance were certainly oriented towards optimizing the wealth and well-being 
of imperial citizens, both in the metropole and in the local form of settlers abroad in certain cases (e.g. Mamdani 1996). In other words, various colonial administrations undoubtedly needed to ensure that their subjects were 'made to live' via initiatives to facilitate the profitability and sustainability of their livelihoods, albeit in ways that sometimes quite violently disciplined the nature of those livelihoods and the distribution of the wealth arising therefrom. For instance, explicitly seeking to illuminate the idiosyncrasies inherent to the exercise of biopower in such a context, Cavanagh's recent study of colonial engagements with forest-dwelling or Dorobo populations in eastern Africa highlights the "peculiar" or context-specific articulation of biopolitics within the British civilizing mission (2017a). State officials construed the forcible dispossession and assimilation of historically forest-dwelling populations as a means of the 'betterment' of Dorobo communities and the forest ecosystems that they had previously inhabited, despite the loss of lands, resources, and underlying forms of livelihood. In turn, Cavanagh develops a conception of "civilizing violence" within the biopolitics of British colonial rule in East Africa, wherein efforts to "make live" were paradoxically wedded to the forcible assimilation of livelihoods and identities into those favored by state administrators.

There is indubitably much scope for political ecologists to trace the empirical contours of actuallyexisting practices of the (colonial) administration of populations and environments, and to draw upon the historical and geographical vagaries of these experiences to nuance Foucault's rather general account of the emergence of biopower in eighteenth-century Europe. Likewise, similar inquiries might be made into the operations of biopower under non-European forms of imperialism, (settler) colonialism, and state formation - such as those practiced, for example, by Japanese, Ethiopian, or Chinese states in different historical periods. ${ }^{3}$ Further still, inquiries might be made into the presence of biopolitical forms of governance (or lack thereof) in systems of combined social and ecological management within pre-colonial states - or, more controversially, within "stateless" societies around the globe (à la Scott 2009). At any rate, there appears to be much scope for the further inductive refinement as opposed to the simple application of biopolitical theory on the basis of both historical and contemporary empirical data.

Beyond biopower? Infopower, ontopower, necropower, geontopower, and the biopolitics of academic neologisms

Various thinkers - primarily in the humanities - have sought to go "beyond" the notion of biopower. Or, failing that, to at least illuminate the ways in which - as Clough and Willse put it - contemporary reformulations of governance and governmentality might provide a "platform for the extension of biopolitics beyond itself" (2011: 3). This has led to a proliferation of neologisms inspired - at least in part - by Foucault's writings on these topics. These include infopower (Koopman 2014), ontopower (Massumi 2015), necropower (Mbembe 2003), and geontopower (Povinelli 2016). Also available are conceptualizations of life politics (Fassin 2011), ethopolitics (Rose 2009), and immunological politics (Esposito 2008; see also Grove 2014c) as opposed to biopolitics. One might observe, half-jokingly, that it remains to be seen which of these neologisms will be "made to live" and which will be "let die" in subsequent generations of writing on these themes.

Two theoretical reformulations are of interest to political ecologists in particular, namely the work of Brian Massumi (2015) and Elizabeth Povinelli (2016) and their concepts of ontopower and geontopower, respectively. Despite the apparent etymological relation between the two terms, and although both are borne from a similar critique of Foucault's notion of biopower, the conceptual substance of each is distinct. As Povinelli describes her notion of geontopower:

The simplest way of sketching the difference between geontopower and biopower is that the former does not operate through the governance of life and the tactics of death but is rather a set of discourse, affects, and tactics used in late liberalism to maintain or shape the coming relationship of the distinction between Life and Nonlife. (2016: 4)

\footnotetext{
${ }^{3}$ For excellent case studies of state formation in non-Western contexts, see Gonzalez-Ruibal (2014) on Ethiopia and Winichakul (1994) on Siam/Thailand. Both contain implicit if not explicit insights about how biopower might operate distinctively in these different historical-geographical milieux.
} 
Povinelli refers to mounting efforts to reframe the relationship between humans and the 'natural' world as not simply one that is biological, or even primarily ecological, but to some degree geophysical or "geontological" as well (Povinelli 2016: 5). Today, these concerns are most obvious in debates about the emergence and dating of the so-called Anthropocene, or a geological epoch primarily defined by the effects of human civilization and economic development upon the Earth system (see also Cavanagh 2014; Dalby 2013).

In such a context, for Povinelli, the distinction between "life" and supposedly inert "nonlife" is increasingly open to question. This seems to be the case where the science of the Anthropocene illuminates the ways in which certain bio-geophysical systems constitute a necessary precondition for the prosperity - as well as, more fundamentally - the very existence of human populations (e.g. Steffen et al. 2015). There are also prevailing ontologies that conceptualize the relation between humans, nonhuman life, and the apparently 'inert' or nonliving environment in distinct ways, from Wall Street commodities traders, to small scale farmers and pastoralists, to various indigenous communities around the globe. These ontologies vary considerably in terms of precisely which combinations of "men and things" (à la Foucault 2007: 134) they consider to be part of "life" as opposed to "nonlife". In turn, for Povinelli, this variability also produces a (geonto)politics of precisely which of these conceptions of the life-nonlife distinction will be encouraged by states or other authorities, and which will be suppressed, marginalized, or disavowed.

Crucially, however, Povinelli does not claim that geontopower has suddenly emerged to somehow succeed biopower; rather, she contends that "biopower (the governance through life and death) has long depended on a subtending geontopower (the difference between the lively and the inert)" (2016: 5). Indeed, rather than marking a kind of epochal shift, Povinelli suggests and that geontopower has long been "self-evident in certain regimes of settler late liberalism" (ibid). Interestingly, this allows her to draw connections between the "geontopolitical" demarcation of the living from the inert, and the subjugation of ontologies that would attribute agency or subjectivity to apparently 'lifeless' entities as pre-modern or irrational under diverse settler colonial regimes in contexts such as Australia, Canada, the United States, and elsewhere.

Despite the implicit etymological similarity with Povinelli's notion of geontopower, Brian Massumi (2015) in fact has something rather different in mind with the derivation of his concept of "ontopower" from Foucault's writings on biopower (see, especially, Büscher 2018). As opposed to the latter concept, the crux of 'ontopolitics' hinges upon the twin problems of emergence - that is, the coming into being of novel system dynamics, risks, or threats - and the related governance problematic of preemption, or the identification and prevention of such types of emergence before they manifest in mature form. Hence, for Massumi, the field of operation for ontopower might be called "prototerritory" as opposed to territory as such, as the goal of its deployment is precisely to preempt a risk or threat "before it actually emerges" (2015: 40). As he puts it, "[a]n environmental power that returns to life's unlivable conditions of emergence in order to bring life back, redirecting its incipience to alter-emergent effect, is an ontopower" (ibid). That is to say, ontopower acts upon a terrain of threats and risks that may not fully exist yet, but which are nonetheless perceptibly emergent, or plausibly in the process of coming into being.

Here, Massumi's (2015) primary example is the US-led 'War on Terror', which has entailed an obsession not only with actually-existing threats against American or other Western targets, but also their detection and suppression in advance via digital or other surveillance, technical pre-emption - such as heightened controls on the availability of weapons or other dangerous materials - and persuasion via diverse 'hearts and minds' campaigns. At first glance, the concept of ontopower might thus strike the skeptical reader as embodying a strange kind of postmodern functionalism; that is, as being overly concerned with the maintenance of certain 'equilibrium' or framework conditions for the survival of particular (usually 'Western') societies and politicaleconomic conditions. Yet, even in his earlier work, Massumi is careful to note the terrain of disequilibrium upon which contemporary forms of governmentality must operate, facing as they do a "churning sea-bed of crisis in the perpetual making" (2009: 154). As various scholars have pointed out, this approach has the effect of nicely positioning Massumi to analyze contemporary discourses of socio-ecological resilience and crisis, which are not characterized by an attempted defense of equilibrium or "homeostatic" conditions, per se, but rather with ensuring the persistence of certain system functions through disorder and into a new "stable" or 
even "desirable" state (see, inter alia, Baldwin 2013; Braun 2013; Cavanagh 2017b; Grove 2014b; Zebrowski 2016: 13).

In political ecology, Bram Büscher in particular has begun to examine the ways in which Massumi's conception of ontopower might be useful for thinking through the stakes of contemporary - and increasingly militarized, securitized, or otherwise violent - forms of 'sustainable' development and biodiversity conservation initiatives (2015, 2016, 2018). Here, Büscher qualifies that he wants "to emphasise that pre-emptive [onto]power is not the end of biopower/biopolitics" (2018: 166). Yet, as he puts it, a "key question for future research will be whether and how biopolitics and biopower are giving way to ontopolitics and ontopower in development and with what effects" (Büscher 2015: 14). The question is surely relevant, provocative, and exciting, though it might also be more broadly formulated to address the relationship between biopower and (ge)ontopower simultaneously. In other words, the stakes of contemporary governance interventions in the name of conservation or environmental change mitigation reflect not only the necessity of the preemption of threats to - and reactivation of certain framework conditions for - the proliferation of life, but also the question of precisely whose ontologies such interventions reflect. Pre-emptive forms of ontopower deployed in the interest of sustaining Western-dominated iterations of global capital, for instance, might simultaneously entail a 'war' of sorts against alternative means of 'being in the world' that present barriers to commodification or the accumulation of capital more generally. Differently put, is preemption also oriented towards preventing the emergence of diverse "alternative sustainabilities" (Cavanagh and Benjaminsen 2017) - or what Povinelli (2014) has termed the "radical otherwise" - that do not envisage the capitalist production of nature "all the way down" (Smith 2007)? This and related questions may provide fertile territory for political ecologies of biopower, (ge)ontopower, and derivative concepts in future.

\section{Conclusion: politics and political ecology after biopower}

This article has sought to review recent literature on the political ecologies of conservation and environmental change mitigation with an eye towards highlighting the biopolitical stakes of many writings in this field. A large and growing number of geographers, anthropologists and political ecologists engage the Foucauldian concept of biopower directly, and in relation to all manner of contemporary environmental problems and processes. Not least, these include global climatic and environmental change, biodiversity conservation, natural resource management, and more specific issues such as food and water security, deforestation, or the governance of infectious disease. Hence, although Foucault is often accused of anthropocentrism or "species chauvinism" (Haraway 2008: 60), this body of work makes clear in painstaking detail that any rigorous examination of contemporary forms of biopolitics and governmentality will inevitably be a "more than human" endeavor.

For all the talk of power and politics in Foucault's work - as well as in the vast and rapidly growing literature that his writings on these themes have inspired - one might be forgiven for being left with the impression that these debates and discussions are paradoxically apolitical. In part, this perception likely arises from Foucault's well-documented aversion to normative concerns, and his reluctance to offer prescriptions or judgments about how power should or should not be deployed in different contexts (e.g. Bernauer and Mahon 2006; Fraser 1981). Pressed on this issue late in his life, Foucault would later reflect that his own politics was ultimately one of revealing the operations and effects of power especially in contexts presumed to be apolitical, such as in the management of institutions like the clinic or the asylum, or in the formulation of governmental programs for the ostensible "betterment" of whole populations (see inter alia, Elden 2016; Philo 2012). Nonetheless, such a position contrasts rather sharply with an understanding of political ecology as an "explicitly normative" field of study, one concerned not only with "the hatchet" of critique or exposing the operations of power, but also with planting "the seed" of more just or sustainable futures (Robbins 2012: 13).

Especially in the mid-to-late 1970s, Foucault's work offered a sort of taxonomy or "topology" (Collier 2009) of power and its various "technologies." His work was primarily analytical or diagnostic rather than overtly political in the sense of encouraging particular forms of resistance or "counter-conduct" (Foucault 1982). Although Foucault brilliantly illuminates the stakes of political struggle in an era of biopolitical approaches to combined social and ecological governance, it is left to us to somehow reconstitute a politics of biopower, or to 
conceive and enact forms of biopolitical governance that might be said to be more socially and environmentally just. In this sense, one could argue that the phrase 'resistance to biopower' is an oxymoron of sorts, particularly if we conceive of biopower - like Foucault's broader view of power itself (e.g. 1982) - as being "everywhere" and "omnipresent", and as "exercised" rather than "held." Accordingly, it might be said that the task of political ecology in this regard is the formulation of a biopolitics that is resolutely affirmative and enacted through a conception of (non)human life that is conceived as widely and as equitably as possible. Notwithstanding Foucault's own aversion to such a task, it is nonetheless one that political ecologists are "explicitly" well positioned to undertake.

\section{References}

Adorno, T. and M. Horkheimer. 2002. Dialectic of enlightenment: philosophical fragments. Stanford: Stanford University Press.

Agamben, G. 1998. Homo sacer: sovereign power and bare life. Stanford: Stanford University Press.

Agamben, G. 2005. State of exception. Chicago: University of Chicago Press.

Agamben, G. 2011. The kingdom and the glory: for a theological genealogy of economy and government. Stanford: Stanford University Press.

Agrawal, A. 2005. Environmentality: technologies of government and the making of subjects. Durham: Duke University Press.

Astuti, R.Y. and A. McGregor. 2015. REDD+ governmentality in Indonesia: governing forest carbon through the REDD+ Task Force. Asia Pacific Viewpoint 56(1): 21-36.

Bakker, K. 2013. Constructing 'public' water: the World Bank, urban water supply, and the biopolitics of development. Environment and Planning D: Society and Space 31(2): 280-300.

Baldwin, A. 2013. Vital ecosystem security: emergence, circulation, and the biopolitical environmental citizen. Geoforum 45: 52-61.

Beck, U. 2008. World at risk. Cambridge: Polity.

Bernauer, J.W. and M. Mahon. 2006. Michel Foucault's ethical imagination. In G. Gutting (ed.). The Cambridge companion to Foucault. Cambridge: Cambridge University Press. Pp. 149-175.

Biermann, C. and R.M. Anderson. 2017. Conservation, biopolitics, and the governance of life and death. Geography Compass 11: e12329.

Biermann, C. and B. Mansfield. 2014. Biodiversity, purity, and death: conservation biology as biopolitics. Environment and Planning D: Society and Space 32(2): 257-273.

Biermann, C. 2016. Securing forests from the scourge of chestnut blight: the biopolitics of nature and nation. Geoforum 75: 210-219.

Bignall, S. and M. Svirsky. 2011. Introduction: Agamben and colonialism. In M. Svirsky and S. Bignall (eds.). Agamben and colonialism. Edinburgh: Edinburgh University Press. Pp. 1-16.

Birkenholtz, T. 2009. Groundwater governmentality: hegemony and technologies of resistance in Rajasthan's (India) groundwater governance. The Geographical Journal 175(3): 208-220.

Bluwstein, J. 2017. Creating ecotourism territories: environmentalities in Tanzania's community-based conservation. Geoforum 83: 101-113.

Bose, P., B. Arts and H. van Dijk. 2012. 'Forest governmentality': a genealogy of subject-making of forestdependent 'scheduled tribes' in India. Land Use Policy 29(3): 664-673.

Brosius, J.P. 1999. Green dots, pink hearts: displacing politics from the Malaysian rain forest. American Anthropologist 101(1): 36-57.

Braun, B. 2000. Producing vertical territory: geology and governmentality in late Victorian Canada. Cultural Geographies 7(1): 7-46.

Braun, B. 2002. The intemperate rainforest: nature, culture, and power on Canada's west coast. Minneapolis: University of Minnesota Press. 
Braun, B. 2011. Governing disorder: biopolitics and the molecularization of life. In R. Peet, P. Robbins and M.J. Watts (eds.). Global political ecology. London: Routledge. Pp. 389-411.

Braun, B. 2013. Power over life: biosecurity as biopolitics. In A. Dobson, K. Barker and S.L. Taylor (eds.). Biosecurity: the socio-politics of invasive species and infectious diseases. London: Routledge. Pp. 4558.

Braverman, I. 2014. Governing the wild: databases, algorithms, and population models as biopolitics. Surveillance and Society 12(1): 15-37.

Braverman, I. 2015. Wild life: the institution of nature. Stanford: Stanford University Press.

Bryant, R. and M.K. Goodman. 2008. A pioneering reputation: assessing Piers Blaikie's contributions to political ecology. Geoforum 39(2): 708-715.

Burchell, G., C. Gordon and P. Miller (eds.). 1991. The Foucault effect: studies in governmentality. Chicago: University of Chicago Press.

Büscher, B. 2015. Life and capital: development and change in the $21^{\text {st }}$ century. Inaugural lecture, Professor of Sociology of Development and Change, Wageningen University. 3 December 2015.

Büscher, B. 2016. Reactivate or die: from biopower to ontopower in the conservation of biological diversity? Invited lecture for the School of Social Sciences, University of Auckland, New Zealand, 26 May 2016. URL: http://www.arts.auckland.ac.nz/en/about/events/2016/5/reactivate-or-die.html (accessed 30 December 2016).

Büscher, B. 2018. From biopower to ontopower? Violent responses to wildlife crime and the new geographies of conservation. Conservation and Society 16(2): 157-169.

Cadman, L. 2009. Life and death decisions in our posthuman(ist) times. Antipode 41(1): 133-158.

Campbell, T. and A. Sitze. 2013. Biopolitics: an encounter. In T. Campbell and A. Sitze (eds.). Biopolitics: a reader. Durham: Duke University Press.

Carney, M.A. 2014. The biopolitics of 'food insecurity': towards a critical political ecology of the body in studies of women's transnational migration. Journal of Political Ecology 21: 1-18.

Cavanagh, C.J. (2014). Biopolitics, environmental change, and development studies. Forum for Development Studies 41(2): 273-294.

Cavanagh, C.J. 2017a. Anthropos into humanitas: civilizing violence, scientific forestry, and the 'Dorobo question' in eastern Africa. Environment and Planning D: Society and Space 35(4): 694-713.

Cavanagh, C.J. 2017b. Resilience, class, and the antifragility of capital. Resilience 5(2): 110-128.

Cavanagh, C.J. and T.A. Benjaminsen. 2015. Guerrilla agriculture? A biopolitical guide to illicit cultivation within an IUCN Category II protected area. Journal of Peasant Studies 42(3-4): 725-745.

Cavanagh, C.J. and T.A. Benjaminsen. 2017. Political ecology, variegated green economies, and the foreclosure of alternative sustainabilities. Journal of Political Ecology 24: 200-341.

Cavanagh, C.J. and D. Himmelfarb. 2015. "Much in blood and money": necropolitical ecology on the margins of the Uganda Protectorate. Antipode 47(1): 55-73.

Cavanagh, C.J., P.O. Vedeld and L.T. Trædal. 2015. Securitizing REDD+? Problematizing the emerging illegal timber trade and forest carbon interface in East Africa. Geoforum 60: 72-82.

Chakrabarty, D. 2009. Provincializing Europe: postcolonial thought and historical difference. Princeton: Princeton University Press.

Chrulew, M. 2011. Managing love and death at the zoo: the biopolitics of endangered species preservation. Australian Humanities Review 50: 137-157.

Clough, P.T. and C. Willse. 2011. Beyond biopolitics: the governance of life and death. In P.T. Clough and C. Willse (eds.). Beyond biopolitics: essays on the governance of life and death. Durham: Duke University Press. Pp. 1-18.

Coleman, M. and K. Grove. 2009. Biopolitics, biopower, and the return of sovereignty. Environment and Planning D: Society and Space 27(3): 489-507. 
Collard, R.C. 2012. Cougar-human entanglements and the biopolitical un/making of safe space. Environment and Planning D: Society and Space 30(1): 23-42.

Collier, S.J. 2009. Topologies of power: Foucault's analysis of political government beyond 'governmentality'. Theory, Culture and Society 26(6): 78-108.

Collier, S.J. and A. Lakoff. 2008. The vulnerability of vital systems: how 'critical infrastructure' became a security problem. In M.A. Dunn and K.S. Kristensen (eds.). The politics of securing the homeland: critical infrastructure, risk and securitisation. London: Routledge. Pp. 40-62.

Collier, S.J. and A. Lakoff. 2015. Vital systems security: reflexive biopolitics and the government of emergency. Theory, Culture and Society 32(2): 19-51.

Comaroff, J. 2007. Beyond bare life: AIDS, (bio)politics, and the neoliberal order. Public Culture 19(1): 197219.

Cupples, J. 2012. Wild globalization: the biopolitics of climate change and global capitalism on Nicaragua's Mosquito Coast. Antipode 44(1): 10-30.

Dalby, S. 2013. Biopolitics and climate security in the Anthropocene. Geoforum 49: 184-192.

Darier, E. 1996. Environmental governmentality: the case of Canada's green plan. Environmental Politics 5(4): 585-606.

Death, C. 2013. The limits of climate governmentality. In J. Stripple and H. Bulkeley (eds.). Governing the climate: new approaches to rationality, power and politics. Cambridge: Cambridge University Press. Pp. 77-94.

Debrix, F. and A.D. Barder. 2012. Beyond biopolitics: theory, violence, and horror in world politics. London: Routledge.

Dempsey, J. 2016. Enterprising nature: economics, markets, and finance in global biodiversity politics. Oxford: Wiley-Blackwell.

Dillon, M. and L. Lobo-Guerrero. 2008. Biopolitics of security in the 21st century: an introduction. Review of International Studies 34: 265-292.

Dressler, W. 2014. Green governmentality and swidden decline on Palawan Island. Transactions of the Institute of British Geographers 39(2): 250-264.

Duffield, M. 2007. Development, security and unending war: governing the world of peoples. Cambridge: Polity.

Dunlap, A. and J. Fairhead. 2014. The militarisation and marketisation of nature: an alternative lens to 'climateconflict'. Geopolitics 19(4): 937-961.

Ek, R. 2006. Giorgio Agamben and the spatialities of the camp: an introduction. Geografiska Annaler: Series B, Human Geography 88(4): 363-386.

Elden, S. 2002. The war of races and the constitution of the state: Foucault's Il faut défendre la société and the politics of calculation. Boundary 2 29(1): 125-151.

Elden, S. 2016. Foucault's last decade. Cambridge: Polity.

Esposito, R. 2008. Bios: biopolitics and philosophy. Minneapolis: University of Minnesota Press.

Evered, K.T. and E.Ö. Evered. 2012. State, peasant, mosquito: the biopolitics of public health education and malaria in early republican Turkey. Political Geography 31(5): 311-323.

Fassin, D. 2011. Humanitarian reason: a moral history of the present. Berkeley, CA: University of California Press.

Fletcher, R. 2010. Neoliberal environmentality: towards a poststructuralist political ecology of the conservation debate. Conservation and Society 8(3): 171-181.

Fletcher, R. 2017. Environmentality unbound: multiple governmentalities in environmental politics. Geoforum. Ahead-of-print. https://doi.org/10.1016/j.geoforum.2017.06.009 (accessed 19 July 2017).

Foucault, M. 1975. Discipline and punish. New York: Pantheon.

Foucault, M. 1978. History of sexuality. Vol. 1: an introduction. New York: Vintage. 
Foucault, M. 1979. On governmentality. Ideology and Consciousness 6: 5-21.

Foucault, M. 1980. Two lectures. In C. Gordon (ed.). Power/knowledge: selected interviews and other writings, 1972-1977. New York: Pantheon. Pp. 78-108.

Foucault, M. 1982. The subject and power. Critical Inquiry 8(4): 777-795.

Foucault, M. 1983. Power and truth. In H.L. Dreyfus and P. Rabinow (eds.). Michel Foucault: beyond structuralism and hermeneutics. Chicago: University of Chicago Press. Pp. 184-204.

Foucault, M. 1991. Governmentality. In G. Burchell, C. Gordon and P. Miller (eds.). The Foucault effect: studies in governentality. Chicago: University of Chicago Press. Pp. 87-104.

Foucault, M. 2003. Society must be defended: Lectures at the Collège de France 1975-76. New York: Picador.

Foucault, M. 2007. Security, territory, population: Lectures at the Collège de France 1977-1978. New York: Picador.

Foucault, M. 2008. The birth of biopolitics: Lectures at the Collège de France 1978-1979. New York: Picador.

Foucault, M. 2015. The punitive society: Lectures at the Collège de France, 1972-1973. New York: Palgrave Macmillan.

Foucault, M. 2017. Subjectivity and truth: Lectures and the Collège de France, 1980-1981. New York: Palgrave Macmillan.

Foucault, M. 2018. Penal theories and institutions: Lectures at the Collège de France, 1971-1972. New York: Palgrave Macmillan.

Fraser, N. 1981. Foucault on modern power: empirical insights and normative confusions. Praxis International 1(3): 272-287.

Giami, A. and C. Perrey. 2012. Transformations in the medicalization of sex: HIV prevention between discipline and biopolitics. Journal of Sex Research 49(4): 353-361.

Goldman, M. 2001. Constructing an environmental state: eco-governmentality and other transnational practices of a 'green' World Bank. Social Problems 48(4): 499-523.

González-Ruibal, A. 2014. An archaeology of resistance: materiality and time in an African borderland. London: Rowman and Littlefield.

Grove, K.J. 2010. Insuring "our common future?" Dangerous climate change and the biopolitics of environmental security. Geopolitics 15(3): 536-563.

Grove, K.J. 2014a. Biopolitics. In C. Death (ed.). Critical environmental politics. London: Routledge. Pp. 2230.

Grove, K.J. 2014b. Biopolitics and adaptation: governing socio-ecological contingency through climate change and disaster studies. Geography Compass 8(3): 198-210.

Grove, K.J 2014c. Agency, affect, and the immunological politics of disaster resilience. Environment and Planning D: Society and Space 32(2): 240-256.

Grove, R.H. 1996. Green imperialism: colonial expansion, tropical island Edens and the origins of environmentalism, 1600-1860. Cambridge: Cambridge University Press.

Grove, R.H. 2002. Climatic fears: colonialism and the history of environmentalism. Harvard International Review 23(4): 50.

Haraway, D. 2008. When species meet. Minneapolis: University of Minnesota Press.

Hardt, M. 2011. The militancy of theory. South Atlantic Quarterly 110(1): 19-35.

Hardt, M. and A. Negri. 2000. Empire. Cambridge: Harvard University Press.

Hardt, M. and A. Negri. 2009. Commonwealth. Cambridge: Belknap Press of Harvard University Press.

Harvey, D. 2014. Seventeen contradictions and the end of capitalism. Oxford: Oxford University Press.

Hellberg, S. 2014. Water, life and politics: exploring the contested case of eThekwini municipality through a governmentality lens. Geoforum 56: 226-236.

Hinchliffe, S. and N. Bingham. 2008. Securing life: the emerging practices of biosecurity. Environment and Planning A 40(7): 1534-1551. 
Hodgetts, T. 2017. Wildlife conservation, multiple biopolitics and animal subjectification: three mammals' tales. Geoforum 79: 17-25.

Hsu, P.D., E.S. Lander and F. Zhang. 2014. Development and applications of CRISPR-Cas9 for genome engineering. Cell 157(6): 1262-1278.

Kelly, A.B. and M. Ybarra. 2016. Introduction to themed issue: "Green security in protected areas". Geoforum 69: 171-175.

Kolås, Å. 2014. Degradation discourse and green governmentality in the Xilinguole grasslands of Inner Mongolia. Development and Change 45(2): 308-328.

Koopman, C. 2014. Michel Foucault's critical empiricism today: concepts and analytics in the critique of biopower and infopower. In J. Faubion (ed.). Foucault now: critical perspectives in Foucault studies. Oxford: Wiley-Blackwell. Pp. 88-111.

Legg, S. 2007. Beyond the European province: Foucault and postcolonialism. In J. Crampton and S. Elden (eds.). Space, knowledge and power: Foucault and geography. Aldershot: Ashgate. Pp. 265-289.

Lemke, T. 2005. "A zone of indistinction"- a critique of Giorgio Agamben's concept of biopolitics. Outlines: Critical Practice Studies 7(1): 3-13.

Lemke, T. 2011. Biopolitics: an advanced introduction. New York: New York University Press.

Li, T.M. 1999. Compromising power: development, culture, and rule in Indonesia. Cultural Anthropology 14(3): 295-322.

Loperena, C.A. 2016. Conservation by racialized dispossession: the making of an eco-destination on Honduras's North Coast. Geoforum 69: 184-193.

Lorimer, J. 2015. Wildlife in the Anthropocene: conservation after nature. Minneapolis: University of Minnesota Press.

Luke, T.W. 1995. On environmentality: geo-power and eco-knowledge in the discourses of contemporary environmentalism. Cultural Critique 31: 57-81.

Luke, T.W. 1999. Environmentality as green governmentality. In Darier, E. (ed.). Discourses of the environment. Oxford: Blackwell. Pp. 121-151.

Luke, T.W. 2009. Developing planetarian accountancy: fabricating nature as stock, service, and system for green governmentality. Current Perspectives in Social Theory 26: 129-159.

Lunstrum, E. 2014. Green militarization: anti-poaching efforts and the spatial contours of Kruger National Park. Annals of the Association of American Geographers 104(4): 816-832.

Lövbrand, E., J. Stripple and B. Wiman. 2009. Earth System governmentality: reflections on science in the Anthropocene. Global Environmental Change 19(1): 7-13.

Malette, S. 2009. Foucault for the next century: eco-governmentality. In S. Binkley and J. Capetillo-Ponce (eds.). A Foucault for the $21^{\text {st }}$ century: governmentality, biopolitics, and discipline in the new millennium. Cambridge: Cambridge Scholars Publishing. Pp. 221-239.

Mamdani, M. 1996. Citizen and subject: contemporary Africa and the legacy of late colonialism. Princeton, NJ: Princeton University Press.

Mansfield, B. 2012. Race and the new epigenetic biopolitics of environmental health. BioSocieties 7(4): 352372.

Marx, K. 1887. Capital: a critique of political economy, Vol. 1. Moscow: Progress Publishers.

Massumi, B. 2009. National enterprise emergency: steps toward an ecology of powers. Theory, Culture and Society 26(6): 153-185.

Massumi, B. 2015. Ontopower: war, powers, and the state of perception. Durham: Duke University Press.

Mbembe, A. 2003. Necropolitics. Public Culture 15(1): 11-40.

Michel, J.B., Y.K. Shen, A.P. Aiden, A. Veres, M.K. Gray, The Google Books Team, J.P. Pickett, D. Hoiberg, D. Clancy, P. Norvig, J. Orwant, S. Pinker, M.A. Nowak and E. Lieberman Aiden. 2011. Quantitative analysis of culture using millions of digitized books. Science 331(6014): 176-182. 
Minca, C. 2015. The biopolitical imperative. In J. Agnew, V. Mamadouh, A.J. Secor and J. Sharp (eds.). The Wiley Blackwell companion to political geography. Oxford: Wiley-Blackwell. Pp. 165-186.

Mitchell, T. 1998. Fixing the economy. Cultural Studies 12(1): 82-101.

Moore, D. S. 1999. The crucible of cultural politics: reworking "development" in Zimbabwe's eastern highlands. American Ethnologist 26(3): 654-689.

Moore, D.S. 2005. Suffering for territory: race, place, and power in Zimbabwe. Durham: Duke University Press.

Morgensen, S.L. 2011. The biopolitics of settler colonialism: right here, right now. Settler Colonial Studies 1(1): 52-76.

Naidoo, K. 2016. Resisting cognitive dissonance: the need to move from system maintenance and protection to system redesign and transformation. Keynote address, 'Political Ecologies of Conflict, Capitalism, and Contestation' International Conference, Wageningen, the Netherlands, 07-09 July 2016. URL: https://www.youtube.com/watch?v=0oJApprna6w (accessed 30 December 2016).

Nally, D. 2008. "That coming storm": the Irish Poor Law, colonial biopolitics, and the Great Famine. Annals of the Association of American Geographers 98(3): 714-741.

Nally, D. 2011. The biopolitics of food provisioning. Transactions of the Institute of British Geographers 36(1): 37-53.

Nel, A. 2015. The choreography of sacrifice: market environmentalism, biopolitics and environmental damage. Geoforum 65: 246-254.

Nelsen, A. 2015. US military agency invests $\$ 100 \mathrm{~m}$ in genetic extinction technologies. The Guardian (4 December 2017). URL: https://www.theguardian.com/science/2017/dec/04/us-military-agency-invests100m-in-genetic-extinction-technologies (last accessed 15 March 2018).

Neumann, R. 2001. Disciplining peasants in Tanzania: from state violence to self-surveillance in wildlife conservation. In: Peluso, N.L. and M.J. Watts (eds.). Violent environments. Ithaca: Cornell University Press. Pp. 305-327.

Oels, A. 2005. Rendering climate change governable: from biopower to advanced liberal government? Journal of Environmental Policy and Planning 7(3): 185-207.

Ojakangas, M. 2005. Impossible dialogue on bio-power: Agamben and Foucault. Foucault Studies 2: 5-28.

Ojakangas, M. 2016. On the Greek origins of biopolitics: a reinterpretation of the history of biopower. London: Routledge.

Peet, R. and M.J. Watts (eds.) 2004. Liberation ecologies: environment, development, social movements. London: Routledge.

Philo, C. 2012. A 'new Foucault' with lively implications - or 'the crawfish advances sideways'. Transactions of the Institute of British Geographers 37(4): 496-514.

Povinelli, E.A. 2011. Economies of abandonment: social belonging and endurance in late liberalism. Durham: Duke University Press.

Povinelli, E. 2014. Interview with Elizabeth Povinelli. Society and Space Open Site. URL: http://societyandspace.com/2014/03/06/interview-with-elizabeth-povinelli-with-mat-coleman-andkathryn-yusoff (accessed 31 December 2016).

Povinelli, E. 2016. Geontologies: a requiem to late liberalism. Durham: Duke University Press.

Rabinow, P. and N. Rose. 2006. Biopower today. BioSocieties 1(2): 195-217.

Rattu, P. and R. Véron. 2016. Towards a Foucauldian urban political ecology of water: rethinking the hydrosocial cycle and scholars' critical engagement. Foucault Studies 21: 138-158.

Reid, J. 2010. The biopoliticization of humanitarianism: from saving bare life to securing the biohuman in postinterventionary societies. Journal of Intervention and Statebuilding 4(4): 391-411.

Reid, J. 2013. Interrogating the neoliberal biopolitics of the sustainable development-resilience nexus. International Political Sociology 7(4): 353-367. 
Reid, J. 2014. Climate, migration, and sex: the biopolitics of climate-induced migration. Critical Studies on Security 2(2): 196-209.

Rentea, S. 2017. Introduction. In S. Prozorov and S. Rentea (eds.). The Routledge handbook of biopolitics. London: Routledge. Pp. 1-20.

Rifkin, M. 2009. Indigenizing Agamben: rethinking sovereignty in light of the "peculiar" status of Native peoples. Cultural Critique 73(1): 88-124.

Rockström, J., W. Steffen, K. Noone, Å. Persson, F. Stuart Chapin III, E.F. Lambin, T.M. Lenton, M. Scheffer, C. Folke, H.J. Schellnhuber, B. Nykvist, C.A. de Wit, T. Hughes, S. van der Leeuw, H. Rodhe, S. Sörlin, P.K. Snyder, P.K. R. Costanza, U. Svedin, M. Falkenmark, L. Karlberg, R.W. Corell, V.J. Fabry, J. Hansen, B. Walker, D. Liverman, K. Richardson, P. Crutzen, and J.A. Foley. 2009. A safe operating space for humanity. Nature 461: 472-475.

Rose, N. 2009. The politics of life itself: biomedicine, power, and subjectivity in the twenty-first century. Princeton, NJ: Princeton University Press.

Rutherford, P. 1993. Foucault's concept of biopower: implications for environmental politics. In I. Thomas (ed.). Ecopolitics VI: interactions and action. Melbourne: Royal Melbourne Institute of Technology.

Rutherford, P. 1999. The entry of life into history. In E. Darier (ed.). Discourses of the environment. Oxford: Blackwell. Pp. 37-62.

Rutherford, S. and P. Rutherford. 2013a. Geography and biopolitics. Geography Compass 7(6): 423-434.

Rutherford, P. and S. Rutherford. 2013b. The confusions and exuberances of biopolitics. Geography Compass 7(6): 412-422.

Schlosser, K. 2008. Bio-political geographies. Geography Compass 2(5): 1621-1634.

Scott, J.C. 2009. The art of not being governed: an anarchist history of upland Southeast Asia. New Haven: Yale University Press.

Shukin, N. 2009. Animal capital: rendering life in biopolitical times. Minneapolis: University of Minnesota Press.

Smith, M. 2011. Against ecological sovereignty: ethics, biopolitics, and saving the natural world. Minneapolis: University of Minnesota Press.

Smith, N. 2007. Nature as accumulation strategy. Socialist Register 43: 16-36.

Sivaramakrishnan, K. 1999. Modern forests: statemaking and environmental change in colonial eastern India. Stanford: Stanford University Press.

Srinivasan, K. 2013. The biopolitics of animal being and welfare: dog control and care in the UK and India. Transactions of the Institute of British Geographers 38(1): 106-119.

Srinivasan, K. 2014. Caring for the collective: biopower and agential subjectification in wildlife conservation. Environment and Planning D: Society and Space 32(3): 501-517.

Srinivasan, K. 2017a. Biopower. In D. Richardson, N. Castree, M.F. Goodchild, A. Kobayashi, W. Liu and R.A. Marston (eds.). The international encyclopedia of geography. Oxford: John Wiley. 6 pp.

Srinivasan, K. 2017b. Conservation biopolitics and the sustainability episteme. Environment and Planning A. Ahead-of-print. https://doi.org/10.1177/0308518X17704198 (accessed 27 July 2017).

Steffen, W., K. Richardson, J. Rockström, S.E. Cornell, I. Fetzer, E.M. Bennett, R. Biggs, S.R. Carpenter, W. de Vries, C.A. de Wit and C. Folke. 2015. Planetary boundaries: guiding human development on a changing planet. Science 347(6223): 1259855.c

Stoler, A.L. 1995. Race and the education of desire: Foucault's history of sexuality and the colonial order of things. Durham: Duke University Press.

Svarstad H., T.A. Benjaminsen and R. Overå. 2018. Power theories in political ecology. Journal of Political Ecology 25: 350-363.

Thompson Reuters. 2009. Most cited authors of books in the humanities. URL: https://www.timeshighereducation.com/news/most-cited-authors-of-books-in-the-humanities2007/405956.article (accessed 20.12.2016). 
Valdiva, G. 2015. Eco-governmentality. In T. Perreault, G. Bridge and J. McCarthy (eds.). The Routledge handbook of political ecology. London: Routledge. Pp. 467-480.

Wang, T. 2015. Green governmentality. In R.L. Bryant (ed.). The international handbook of political ecology. Cheltenham: Edward Elgar. Pp. 318-331.

Webometrics. 2016. 1,360 highly cited Researchers ( $\mathrm{h}>100)$ according to their Google Scholar Citations public profiles. URL: http://www.webometrics.info/en/node/58 (accessed 16/12/2016).

Winichakul, T. 1994. Siam mapped: a history of the geo-body of a nation. Honolulu: University of Hawaii Press.

Wolfe, C. 2013. Before the law: humans and other animals in a biopolitical frame. Chicago: University of Chicago Press.

Yeh, E.T. 2005. Green governmentality and pastoralism in western China: 'converting pastures to grasslands'. Nomadic Peoples 9(1-2): 9-30.

Youatt, R. 2008. Counting species: biopower and the global biodiversity census. Environmental Values 17(3): 393-417.

Youdelis, M. 2013. The competitive (dis)advantages of ecotourism in Northern Thailand. Geoforum 50: 161171.

Zebrowski, C. 2016. The value of resilience: securing life in the twenty-first century. London: Routledge. 